\title{
Assessing the quality of Portuguese child care programs for toddlers
}

\author{
Sílvia Barros ${ }^{\mathrm{a}, *}$, Cecília Aguiar ${ }^{\mathrm{b}}$ \\ a Escola Superior de Educação, Instituto Politécnico do Porto; University of Porto, Department of Psychology and Educational Sciences, Porto, Portugal \\ b UIPCDE, Instituto Superior de Psicologia Aplicada, Lisboa, Portugal
}

\section{A R T I C L E I N F O}

\section{Article history:}

Received 4 February 2009

Received in revised form

21 December 2009

Accepted 23 December 2009

We dedicate this paper to the memory of Professor Joaquim Bairrão (1935-2007), outstanding scientist and mentor.

Keywords:

Quality

Toddler child care

ITERS-R

Portugal

\begin{abstract}
A B S T R A C T
The purpose of this study was to describe the quality of toddler child care classrooms in the district of Porto, in the north of Portugal. One hundred and sixty classrooms for children between 1 and 3 years of age participated in this study. Results suggested the existence of poor average quality and absence of good-quality classrooms. Child-adult ratio was a statistically significant predictor of overall child care quality (with lower ratios associated with higher quality). The results of this study provide information on the applicability of ITERS-R to a new cultural and linguistic context, suggesting the need to enhance the quality of Portuguese programs serving toddlers.
\end{abstract}

(c) 2010 Elsevier Inc. All rights reserved.

Portuguese families with children between 4 months and 3 years of age are served by four types of child care and education programs: crèches (infant-toddler child care centers), mini-crèches (infant-toddler child care for 12-15 children), official nannies (family child care homes), and family crèches (groups of 12-20 family child care homes), all dependent on the Ministry of Labor and Welfare (Vasconcelos, Orey, Homem, \& Cabral, 2002). The number of child care and education services for infants and toddlers has been progressively increasing in Portugal. Coverage rate has increased from 12.65\% in 1996 (Vasconcelos et al., 2002) to 21.5\% in 2003 (Instituto da Segurança Social, 2005c).

Currently, project PARES (Programa de Alargamento da Rede de Equipamentos Sociais), a governmental program designed to increase social protection and support families by extending the network of social programs, is funding a $50 \%$ increase in the number of infant-toddler child care centers (Instituto da Segurança Social, 2005c). The goal is to achieve a 33\% coverage rate in 2010 (Instituto da Segurança Social, 2005c). However, it is important that the investment made in increasing the number of child care programs accessible to families with young children is accompanied with an effort to assure their quality. This fact is acknowledged by the Portuguese government agency responsible for infant and toddler child care in Portugal - The Social Solidarity Institute - as suggested by the recent distribution of documents that provide an Infant Toddler Child Care Quality Assessment Model and a Key-Processes Manual (Instituto da Segurança Social, 2005a, 2005b).

Several studies have consistently demonstrated an association between the quality of child care programs and children's short-term and long-term developmental outcomes (National Association for the Education of Young Children [NAEYC], 1997). For example, in the United States of America (USA), the Cost, Quality, and Child Outcomes in Child Care Centers Study

\footnotetext{
is Partial contents of this paper were previously published in Portuguese in Avaliação Psicológica: Formas e Contextos, the proceedings of the XI Conferência Internacional Avaliação Psicológica: Formas e Contextos, Braga, Portugal.

* Corresponding author at: UTC de Psicologia, Escola Superior de Educação do IPP, Rua do Dr. Roberto Frias, 602, 4200-465, Porto, Portugal.

E-mail addresses: silviabarros@ese.ipp.pt (S. Barros), caguiar@ispa.pt (C. Aguiar).
} 
(Peisner-Feinberg \& Burchinal, 1997) found a positive association between children's cognitive and social developmental outcomes and the quality of their experiences in child care programs, after accounting for children's and families' characteristics. Results further indicated that (a) high-quality care positively predicts academic performance; (b) children who have traditionally been considered as being "at risk" are more influenced by the quality of child care experiences; (c) different aspects of quality influence different development areas - the quality of child care classroom practices was related to children's cognitive development, while the closeness of the teacher-child relationship influenced children's social development through the early school years; (d) high-quality child care continues to positively predict children's performance over time, in many cases through the end of second grade (Peisner-Feinberg \& Burchinal, 1997; Peisner-Feinberg et al., 2000). Another major USA study, the National Institute on Child Health and Human Development [NICHD] Study of Early Child Care (NICHD, 2005), found that lower quality child care predicted less harmonious mother-child relationships, increased probability of insecure attachment of children with less sensitive mothers, lower language and cognitive outcomes, and lower school readiness competencies.

These results highlight the need to assess and enhance the quality of child care and education structures. In Portugal, few studies have examined the quality of care programs serving infants and toddlers. In 2001, a small study ("Creches e jardins-deinfância", 2001), based on the inspection of 25 child care centers (20 of which serving infants and toddlers), found worrying conditions in adult-child ratio, group size, outdoor and indoor facilities and equipments, and hygiene and safety. Likewise, the Organization for Economic Co-operation and Development [OECD] $(2000,2001)$ expressed concern about the quality of education and care programs serving Portuguese infants and toddlers, recommending the implementation of self-assessment and inspection procedures. In 2002, Aguiar, Bairrão, and Barros observed 30 toddler child care classrooms, in the district of Porto, reporting average poor quality and absence of good-quality programs for toddlers. Using the same participants, Pessanha (2005) found a small positive effect of toddler child care quality on children's developmental outcomes.

Despite varying views on quality, there has been some consensus, at least in Europe, USA, and other industrialized countries, around the thought that quality is related to the physical and social characteristics of the settings where child care and education take place and to staff characteristics (Bairrão, 1998). For example, NAEYC (1998) defined a high-quality program as one that ensures a safe and stimulating environment that promotes children's physical, social, emotional, aesthetic, intellectual, and language development, while being sensitive to families' needs and preferences. According to Harms and Clifford (1993), the most agreed on criteria to determine quality include health and safety (licensing criteria, compliance with sanitary and health criteria); interactions (responsive and warm adult-child interactions); curriculum (developmentally appropriate activities, balance of child-initiated/teacher-initiated activities, etc.); and staff (limited group size, appropriate adult-child ratio, and staff training). Based on these criteria, Harms, Cryer, and Clifford (1990) developed The Infant/Toddler Environment Rating Scale - ITERS, a scale designed to assess the global quality of educational programs serving children from birth to 30 months of age. The revised edition of ITERS (the Infant/Toddler Environment Rating Scale - Revised Edition, ITERS-R) was published in 2003 (Harms, Cryer, \& Clifford, 2003) and translated into Portuguese in 2004 (Harms et al., 2003; Harms, Cryer, \& Clifford, 2004).

The definition of quality underlying ITERS and ITERS-R includes research's results, professional values, and empirical knowledge, and is consistent with the Criteria for Quality Early Childhood Programs, defined by the NAEYC (1998) and with the goals or requirements of the Child Development Associate - CDA (CDA National Credentialing Program, 1984, as cited in Harms, Cryer, \& Clifford, 1999). The ITERS is considered a process measure (Vandell \& Wolfe, 2000), the quality dimension more directly experienced and felt by children (Cryer \& Burchinal, 1997). According to Vandell and Wolfe (2000), child care processes relate to the experiences that occur in child care settings, including children's interactions with caregivers and peers and their participation in different activities.

Research has demonstrated that the ITERS/ITERS-R and/or the Early Childhood Environment Rating Scale - ECERS (Harms \& Clifford, 1980) and its revised version (ECERS-R, Harms, Clifford, \& Cryer, 1998) correlate with other indicators of child care quality, namely structural characteristics (e.g., Cost, Quality, \& Child Outcomes Study Team, 1995; Vandell \& Wolfe, 2000) such as staff-child ratio, numbers of adults and children in the classroom, caregiver education, training, age, wage, and years of teaching experience, and type of center (i.e., for-profit or non-profit). Higher quality has generally been observed in classrooms with less children per adult (e.g., Cost et al., 1995; Cryer, Tietze, Burchinal, Leal, \& Palacios, 1999; Phillips, Mekos, Scarr, McCartney, \& Abbott-Shim, 2000), smaller group sizes (e.g., European Child Care and Education Study Group, 1997; Gevers Deynoot-Schaub \& Riksen-Walraven, 2005; Goelman, Doherty, Lero, LaGrange, \& Tougas, 2000), and more adults (Goelman et al., 2000). However, some studies did not confirm the association between process quality and some of these specific structural dimensions. For instance, Gevers Deynoot-Schaub and Riksen-Walraven (2005) did not find an association between ITERS overall score and adult-child ratio and, in Portugal, Abreu-Lima and Nunes (2006) did not find an association between ECERS-R scores and group size or adult-child ratio. Children's age group has not been found to correlate with preschool quality global scores in Portugal, Germany, and Spain (European Child Care and Education Study Group, 1997). However, in toddler child care classrooms, higher quality has been observed in classrooms for older toddlers (Aguiar, Bairrão, \& Barros, 2002). The association between process quality measures and teachers' age and experience is not consistent, with studies showing no associations (e.g., Gevers Deynoot-Schaub \& Riksen-Walraven, 2005), negative associations (Pessanha, 2005; van Ijzendoorn, Taveccio, Stams, Verhoeven, \& Reiling, 1998), and positive associations (e.g., Bryant, Burchinal, Lau, \& Sparling, 1994). On the other hand, research suggests teachers' wages may be one of the strongest correlates of process quality (e.g., Phillips et al., 2000). Another clear positive association has been found between global quality and teachers' education and training, with more highly educated and trained teachers providing higher quality environments than less 
educated and trained teachers (e.g., Aguiar et al., 2002; Cost et al., 1995; Goelman et al., 2000). Although less frequently studied, the type of center was found to correlate with global quality, with non-profit or subsidized centers scoring higher than for-profit centers on process quality measures (e.g., Aguiar et al., 2002; Gevers Deynoot-Schaub \& Riksen-Walraven, 2005).

In a national context characterized by (1) a great demand for structures that allow families to conciliate work and family life, (2) a scarce supply of education and care services for infants and toddlers, and (3) empirical indicators of insufficient quality of such services, there is a real necessity to thoroughly examine the characteristics of programs serving children in early stages of development. Therefore, the main goals of this study were (1) to investigate the applicability of ITERS-R to a new culture and language environment by examining the psychometric properties of data collected using the Portuguese translation, (2) to describe the characteristics of child care and education settings for children under 3 years of age, and (3) to examine the associations among overall process quality and selected structural features of toddler child care classrooms. While the first two goals are clearly descriptive and, thus, no research hypotheses were formulated, the following hypotheses specify our expectations regarding the third goal: process quality would be higher (a) in non-profit than in for-profit centers, (b) in classrooms with lower child-adult ratios than in classrooms with higher child-adult ratios, (c) in classrooms with a lead teacher with a university degree in early childhood education than in classrooms with a lead adult without a university degree, (d) when teachers receive higher wages, and (e) in classrooms serving older toddlers than in classrooms serving younger toddlers.

\section{Method}

\subsection{Participants}

One hundred and sixty toddler child care classrooms, from 160 centers randomly selected from a list of child care centers in the district of Porto, participated in this study. Porto is the second largest city in Portugal, with a metropolitan area of approximately 1,500,000 inhabitants (Instituto Nacional de Estatística, 2005). We used stratified random selection in order to select 80 non-profit private centers and 80 for-profit private centers. The participation rate for non-profit centers was $96 \%$ and the participation for for-profit centers was $69 \%$.

In each child care center, we observed a single classroom, in a total of 65 classrooms for children between 1 and 2 years old, 80 classrooms for children between 2 and 3 years old, and 15 classrooms for children between 1 and 3 years old. Although classrooms serving infants (from the age of 4 months) were available, they were not included in the present study because collection of additional measures not reported here was not possible in this age group.

The number of children in each classroom ranged from 4 to $30(M=12.94, S D=4.62)$ and the number of adults varied between 1 and $5(M=2.02, S D=0.76)$. Child-adult ratio ranged from 2:1 to 17:1 $(M=6.97: 1, S D=2.82: 1)$. These classrooms included 323 adults and served 2070 children.

In 132 classrooms, the lead adult (i.e., the adult responsible for providing all or most of the direct work with children) was a trained teacher (i.e., a teacher with a college degree in early childhood education), and in 28 classrooms the lead adult was an untrained teacher (i.e., a teacher's aid without a college degree). All lead adults will be named teachers during the course of this paper.

Teachers' education ranged from 5 to 18 years of formal schooling $(M=14.88, S D=2.41)$, with untrained teachers reporting between 5 and 16 years of education and trained teachers reporting having a bachelors' degree $(n=32)$, a licentiate degree $(n=97)$, or a post-graduate degree $(n=3)$. Teachers' age ranged from 21 to 52 years of age $(M=32.27, S D=6.93)$ and teachers' experience ranged from 2 months to 32 years $(M=8.09, S D=6.66)$.

\subsection{Instruments}

Global quality of individual classrooms was assessed using the Portuguese translation of the Infant/Toddler Environment Rating Scale-Revised Edition (Harms et al., 2003). The translation of ITERS-R used in this study was conducted by the first author, under the supervision of a senior scientist specialized in the field of early childhood education, and is currently under revision for publication purposes. The ITERS-R consists of 39 items, organized under seven categories or conceptually defined subscales: I - Space and Furnishings, II - Personal Care Routines, III - Listening and Talking, IV - Activities, V Interaction, VI - Program Structure, and VII - Parents and Staff. Each item is presented as a 7-point scale, with descriptors for 1 (inadequate), 3 (minimal), 5 (good), and 7 (excellent).

Using the procedure adopted by other studies (e.g., Tietze, Cryer, Bairrão, Palacios, \& Wetzel, 1996), due to the presence of missing values, permitted by the scale, items 21 (sand and water play), 23 (use of TV, video, and/or computer), 31 (group play activities), 32 (provisions for children with disabilities), and 36 (staff interaction and cooperation) were excluded from analyses. Cronbach's alpha coefficient on the overall scale was .75 when using all 39 items and .83 when using 34 items. These results suggest that a single construct is measured by ITERS-R. Similar (see Vermeer et al., 2008) and higher (see Bisceglia, Perlman, Schaack, \& Jenkins, 2009) alpha coefficients were previously reported for the ITERS-R overall score.

We also computed internal consistency coefficients for data obtained in each of the conceptually defined subscales (see Table 1). Alpha coefficients are lower than those reported by Bisceglia et al. (2009) for all subscales and suggest caution should be used when conducting analyses at the subscale level. 
Table 1

Cronbach's alphas for the ITERS-R subscales.

\begin{tabular}{|c|c|c|c|}
\hline & $N$ & \# of items & $\alpha$ \\
\hline \multicolumn{4}{|l|}{ I } \\
\hline Space and Furnishings & 160 & 5 & .51 \\
\hline \multicolumn{4}{|l|}{ II } \\
\hline Personal Care Routines & 160 & 6 & .31 \\
\hline \multicolumn{4}{|l|}{ III } \\
\hline Listening and Talking & 160 & 3 & .66 \\
\hline \multicolumn{4}{|l|}{ IV } \\
\hline Activities & 94 & 10 & .53 \\
\hline Activities without items 21 and 23 & 160 & 8 & .55 \\
\hline \multicolumn{4}{|l|}{ V } \\
\hline Interaction & 160 & 4 & .76 \\
\hline \multicolumn{4}{|l|}{ VI } \\
\hline Program Structure & 13 & 4 & .37 \\
\hline Program Structure without item 32 & 127 & 3 & .18 \\
\hline Program Structure without items 31 and 32 & 160 & 2 & .35 \\
\hline \multicolumn{4}{|l|}{ VII } \\
\hline Parents and Staff & 136 & 7 & .53 \\
\hline
\end{tabular}

Information on child care structural features was collected using a questionnaire designed for that purpose. We collected data on group size, number of adults in the classroom, type of center (for-profit or non-profit), children's age group, and lead teacher's education.

\subsection{Procedure}

\subsubsection{Training}

Previous to the ITERS-R translation and use, the first author participated in an intensive training, lead by the authors of the scale, at the University of North Carolina at Chapel Hill. Later on, two other observers were trained by the first researcher using the materials recommended by the authors of the scale, namely the training video (Harms \& Cryer, 2003). Following this procedure, the three observers conducted training sessions in 16 toddler child care classrooms, aiming at $85 \%$ interrater agreement, within one scale point. The mean interrater percent agreement, within one scale point, for these 16 classrooms, was $88 \%$.

\subsubsection{Data collection}

All data were collected between September 2004 and October 2005, by these three researchers. As suggested by scale authors, each observer remained with the group of children for at least $3 \mathrm{~h}$ in order to observe classroom main routines and activities, between arrival and nap. All classrooms were observed during the morning, the period of greatest activity among toddler child care classrooms. Following the observation of each classroom, observers conducted a small interview with the lead teacher, in order to score all indicators in each item and to collect information on classroom structural features.

Interobserver agreement checks were conducted during the data collection procedure, across 44 agreement sessions ( $27.5 \%$ of the 160 classrooms). Interrater exact percent agreement ranged from $43.18 \%$ to $95.45 \%(M=77.32, S D=14.82)$ and interrater within one scale point percent agreement ranged from $84.09 \%$ to $100 \%(M=95.87, S D=4.55)$. Weighted kappa ranged from -.03 to $.95(M=.69, S D=.24)$.

\section{Results}

Overall mean results on ITERS-R ranged from 1.62 to $4.09(M=2.84, S D=.48)$, presenting a normal distribution. Sixty one percent of classrooms were given scores that suggest inadequate quality (i.e., with an overall score under 3 ) and only $39 \%$ of classrooms were given scores that indicated minimal quality (i.e., with an overall score between 3 and 5). Within the participating classrooms, there were no high-quality classrooms or, in other words, classrooms that consistently implemented developmentally appropriate practices (i.e., with an overall score equal to or greater than 5).

Table 2 presents descriptive statistics for ITERS-R subscales and items. Mean subscale scores varied between 1.67 (Personal Care Routines) and 3.70 (Interaction). Three of the seven subscales presented mean scores below 3 (i.e., minimal quality) and none of the subscales scored higher than 4 .

Mean results at the item level ranged from 1.06 (diapering/toileting) to 4.41 (staff continuity). About half of the items presented mean scores that indicate the presence of minimal quality, while the remaining half presented mean scores that suggest the provision of poor quality child care. Twenty-one of the 34 items were scored between 1 and 7 . Of the remaining 13 items, all presented minimal ratings of 1, except for item number 5 (display for children). Regarding maximum scores, items 9 (diapering/toileting), 10 (health practices), 11 (safety practices), 22 (nature/science), and 24 (promoting acceptance 
Table 2

Descriptive statistics for ITERS-R items and subscales.

\begin{tabular}{|c|c|c|c|}
\hline & Mean & $S D$ & Minimum-Maximum \\
\hline I. Space and Furnishings & 3.33 & 0.74 & $1.60-5.60$ \\
\hline 1. Indoor space & 3.44 & 1.34 & $1-7$ \\
\hline 2. Furniture for routine care and play & 3.16 & 1.61 & $1-7$ \\
\hline 3. Provision for relaxation and comfort & 3.10 & 1.09 & $1-7$ \\
\hline 4. Room arrangement & 3.16 & 1.31 & $1-7$ \\
\hline 5. Display for children & 3.78 & 0.97 & $2-6$ \\
\hline II. Personal Care Routines & 1.67 & 0.53 & $1.00-3.33$ \\
\hline 6. Greeting/departing & 2.37 & 1.98 & $1-7$ \\
\hline 7. Meals/snacks & 1.64 & 1.12 & $1-5$ \\
\hline 8. Nap & 1.19 & 0.73 & $1-7$ \\
\hline 9. Diapering/toileting & 1.06 & 0.31 & $1-4$ \\
\hline 10. Health practices & 1.54 & 0.61 & $1-4$ \\
\hline 11. Safety practices & 2.25 & 1.16 & $1-4$ \\
\hline III. Listening and Talking & 3.36 & 0.98 & $1.00-5.67$ \\
\hline 12. Helping children understand language & 4.24 & 1.33 & $1-6$ \\
\hline 13. Helping children use language & 4.22 & 1.43 & $1-7$ \\
\hline 14. Using books & 1.61 & 1.02 & $1-7$ \\
\hline IV. Activities & 2.44 & 0.56 & $1.13-4.00$ \\
\hline 15. Fine motor & 4.05 & 1.21 & $1-7$ \\
\hline 16. Active physical play & 1.79 & 0.88 & $1-6$ \\
\hline 17. Art & 3.11 & 1.36 & $1-7$ \\
\hline 18. Music and movement & 2.39 & 1.24 & $1-6$ \\
\hline 19. Blocks & 1.79 & 1.23 & $1-6$ \\
\hline 20. Dramatic play & 3.51 & 1.41 & $1-6$ \\
\hline 22. Nature/science & 1.61 & 1.05 & $1-4$ \\
\hline 24. Promoting acceptance of diversity & 1.31 & 0.51 & $1-4$ \\
\hline V. Interaction & 3.70 & 1.10 & $1.25-6.50$ \\
\hline 25. Supervision of play and learning & 3.38 & 1.71 & $1-7$ \\
\hline 26. Peer interaction & 4.36 & 1.06 & $1-6$ \\
\hline 27. Staff-child interaction & 3.94 & 1.61 & $1-7$ \\
\hline 28. Discipline & 3.14 & 1.32 & $1-7$ \\
\hline VI. Program Structure & 2.56 & 0.65 & $1.00-5.00$ \\
\hline 29. Schedule & 3.21 & 0.77 & $1-7$ \\
\hline 30. Free play & 2.08 & 0.77 & $1-7$ \\
\hline VII. Parents and Staff & 3.44 & 0.74 & $1.50-5.14$ \\
\hline 33. Provisions for parents & 3.33 & 1.18 & $1-7$ \\
\hline 34. Provisions for personal needs of staff & 3.72 & 0.90 & $1-7$ \\
\hline 35. Provisions for professional needs of staff & 4.26 & 1.65 & $1-7$ \\
\hline 37. Staff continuity & 4.41 & 1.77 & $1-7$ \\
\hline 38. Supervision and evaluation of staff & 2.41 & 1.28 & $1-7$ \\
\hline 39. Opportunities for professional growth & 2.04 & 1.14 & $1-7$ \\
\hline
\end{tabular}

of diversity) scored 4, item 7 (meals/snacks) scored 5, and items 5 (display for children), 12 (helping children understand language), 16 (active physical play), 18 (music and movement), 19 (blocks), 20 (dramatic play), and 26 (peer interaction) scored 6. Maximum scores obtained in some items may raise some concern regarding their sensitivity.

Kurtosis and skewness values for items 8, 9, 14,16,24, 29, 30,34, and 39 indicate the violation of the normality assumption. Once more, and excluding results obtained on item 34 (an item with greater score variability and higher mean scores), these results seem to reflect concentration of scores on lower scale points due to lack of good-quality care in observed classrooms.

In order to examine the associations among overall process quality and structural features of toddler child care classrooms (i.e., teachers' professional status/training, children's age group-determined on the base of the centers' distribution of children across same-age classrooms and excluding the 15 classrooms for children between 1 and 3 years of age, type of center, child-adult ratio, and teachers' monthly wage) we used standard multiple regression analyses. All variables were entered in the model in one step as our hypotheses did not specify subtypes of structural features or the relative contribution of structural variables measured at different levels. Variables included in the regression model were either dichotomous (teachers' professional status, children's age group, and type of center), or normally distributed interval variables. Teachers' professional status was coded 0 for trained teachers and 1 for untrained teachers, type of center was coded 0 for non-profit centers and 1 for for-profit centers, and age group was coded 0 for 1 -year-old classrooms and 1 for 2-year-old classrooms. Missing values on teacher monthly income (valid $N=110$ ) and elimination of two outliers for the child-adult ratio variable limited the number of classrooms included in the regression model to 108. A logarithm transformation was performed on child-adult ratio to improve normality. For descriptive purposes, correlation coefficients between classroom overall quality and structural predictors, and among predictors, are presented in Table 3. Regression results (see Table 4) suggest only 
Table 3

Intercorrelations between overall classroom quality and structural variables.

\begin{tabular}{|c|c|c|c|c|c|}
\hline & 1 & 2 & 3 & 4 & 5 \\
\hline 1. Classroom quality & - & & & & \\
\hline 2. Professional status ( $0=$ trained $)$ & $-.27^{* *}$ & - & & & \\
\hline 3. Age group & .13 & $-.25^{* *}$ & - & & \\
\hline 4. Type of center $(0=$ non-profit $)$ & -.16 & $.31^{* * *}$ & .00 & - & \\
\hline 5. Child-adult ratio (log) & $-.28^{* *}$ & .14 & $.32^{* * *}$ & $.25^{* *}$ & - \\
\hline 6. Monthly income & $.18^{*}$ & $-.59^{* * *}$ & .09 & $-.30^{* * *}$ & -.15 \\
\hline
\end{tabular}

Table 4

Summary of regression analysis for structural variables predicting overall classroom quality $(N=108)$.

\begin{tabular}{lrrrr}
\hline Variable & \multicolumn{1}{c}{$B$} & SE B & \multicolumn{1}{c}{$\beta$} \\
\hline Professional status & -0.19 & .14 & -.16 \\
Age group & 0.18 & .10 & .19 \\
Type of center & -0.02 & .09 & .33 \\
Child-adult ratio (log) & -0.91 & .30 & -.02 & $-.31^{*}$ \\
Monthly income & 0.00 & .00 & .01 \\
\hline
\end{tabular}

${ }^{*} p<.01$.

child-adult ratio was a statistically significant predictor of overall process quality, after accounting for the effects of the remaining variables $[R=.40, F(5,102)=3.85, p<.01]$. Effect size estimates suggest a medium effect of the model $\left(f^{2}=.19\right)$.

We also computed Spearman's rho correlations between classroom quality and classroom structural features that were not normally distributed (and normality could not be achieved through transformations), such as group size, number of adults in the classroom, teachers' education (years), teachers' age, and teachers' experience. We found small statistically significant positive associations between overall quality and group size $\left(r_{\mathrm{s}}=.23, p=.003\right)$ and teachers' education $\left(r_{\mathrm{s}}=.29\right.$, $p=.000)$; and a moderate positive association between quality and number of adults in the classroom $\left(r_{\mathrm{s}}=.41, p=.000\right)$. Note that both group size and number of adults in the classroom were moderately associated with type of center, with bigger groups attending non-profit centers $(r=-.44, p=.000)$ and less adults working in for-profit centers $(r=-.56, p=.000)$.

\section{Discussion}

Results from this study suggest that toddlers attending child care classrooms in the district of Porto, Portugal, are receiving poor quality care and education that does not appropriately respond to children's basic health, safety, and developmental needs. Only 39\% of the observed classrooms provided sufficient quality that minimally met custodial care needs and, to some small degree, responded to children's basic developmental needs. Results further suggest the absence of developmentally appropriate practices or good quality in programs serving children from this age group.

These findings support results previously reported by Aguiar et al. (2002) and strengthen the empirically based concerns about the characteristics of extra-familiar settings available to families with young children in Portugal. Although particularly salient in the Portuguese context (given the apparent absence of high-quality toddler child care), concerns about the quality of child care and education programs for children under 3 years of age are felt in other countries. For example, in the USA, according to the Cost et al. (1995), only 8\% of the classrooms for children under 3 years of age presented high quality, capable of promoting children's health and cognitive and social behavior, opposed to $40 \%$ of classrooms that presented low or inappropriate quality, considered eventually dangerous for children's health and safety, and damaging to children's cognitive and social development. More recent data on infant and toddler child care quality in the USA indicated that only $9 \%$ of children attended excellent quality programs and $29.6 \%$ attended good-quality programs, whereas $53.2 \%$ of children attended mediocre quality programs and 8.1\% attended low-quality programs (NICHD, 2000, 2005). Nevertheless, mean scores obtained in the present study $(M=2.84)$ are substantially lower than those recently reported by Hestenes, Cassidy, Hegde, and Lower (2007). Using the same quality measure and a larger sample, these authors reported a global quality score that suggests average quality care and education is available to American infants and toddlers $(M=4.89)$. Within the European context, and considering studies that used ITERS or ITERS-R, we highlight the Dutch results reported by Vermeer et al. (2008), showing that although in 1995 no center received low level quality scores, in 2001, 6\% of centers were reported to provide low-quality child care services, while, in 2005, the percentage of low-quality centers increased to $36 \%$. On the other hand, no group received good or excellent quality ratings in 2001, similarly to the Portuguese sample. In Greece, results were not so different: none of the child care centers assessed using the ITERS were found to have high-quality scores, but rather ranged between "minimal" and "good" quality (Petrogiannis, 2002). Better results were found in the United Kingdom (UK), where $23 \%$ of centers achieved a total score of 5 or higher, with only $7 \%$ scoring less than 3 (Mathers \& Sylva, 2007). 
Mathers and Sylva believe the relatively high-quality ratings may be due to the legislative regulation in the UK and also to the additional resources participating centers had access to, due to involvement in the Neighbourhood Nursery Initiative. Despite the similarities between Portugal and some other European countries regarding the nonexistence of centers with good or excellent scores, the Portuguese mean scores are lower than those from the Netherlands $(M=3.40)$ (Vermeer et al., 2008), Greece $(M=3.50)$ (Petrogiannis, 2002), Germany $(M=3.21)$ (Tietze \& Cryer, 2004), and UK $(M=4.40)($ Mathers \& Sylva, 2007); the magnitude of differences suggests real-life practical effects, with Portuguese children experiencing lower quality experiences, when compared to children from other European countries and USA.

Analyses of results at the item level allow us to elaborate on a profile of toddler child care classrooms in the district of Porto. Areas of major concern, that is, dimensions where quality of care is most inappropriate, included (a) health requirements, (b) hygiene procedures before and during meals, diapering, and toileting, (c) availability and use of books, (d) frequency of active outdoor physical play, (e) availability of blocks, (f) availability of nature and science materials and activities, and (g) encouragement of acceptance of cultural, ethnic, ability, and role diversity. Low scores on such items may, among other disadvantages, place children at increased risk of infections and limit children's opportunities to develop language and literacy skills, critical scientific reasoning, and positive attitudes toward diversity. In contrast, relative strengths of participating classrooms, that is, dimensions where quality of care ensured minimal response to children's developmental needs, included (a) materials and activities to promote receptive and expressive language, (b) availability of fine motor materials and activities, (c) promotion of peer interaction, (d) continuity of staff, and (e) provisions for the professional development of staff members.

Results on the item level are reinforced by subscale results, although we should be cautious at this level given the low internal consistency values. In fact, Personal care routines, Activities, and Program structure had the lowest results, and did not reach the minimal quality rating. Vermeer et al. (2008) also reported the lowest scores for the subscales of Personal care routines and Activities and higher scores for the Interaction subscale in the Netherlands. Similar results were found in the UK but not in Greece, where the ITERS subscale Personal care routines had the second highest mean $(M=4.0)$, following the Interaction subscale (Petrogiannis, 2002). These results may suggest ITERS-R is more demanding at the health, hygiene, materials, and activities requirements or, for some reason, centers and teachers are less prepared to assure those requirements. Mathers, Linskey, Seddon, and Sylva (2007) concluded that the ECERS and ITERS approach to personal care and hygiene is often more demanding than the UK National Standards. In Portugal, although parents and teachers agree on the high importance of those items (Barros, 2007), the national legislation and orientations are too broad to provide specific guidance.

The small to moderate statistically significant associations among child care quality and selected structural features of the participating classrooms seem to mirror the relative importance of physical and organizational characteristics of child care programs when considering the global quality of children's educational experiences. Interestingly, associations among child care quality and group size, number of adults, and child-adult ratio suggest that classrooms with a larger number of children and a larger number of adults are given higher quality scores, although classrooms with smaller child-adult ratios are given higher quality scores. Regression analyses suggested that child-adult ratio was in fact a statistically significant predictor of overall quality, after accounting for the effects of other structural variables. Due to data distribution properties, we could not include important structural features in the regression analyses. However, Spearman's correlation coefficients suggest that the unexpected positive association between group size and overall quality may be due to type of center, considering that in this study, non-profit centers had bigger groups of children but also had more teachers with a university degree, lower child-staff ratios, and higher wages than for-profit centers.

ITERS-R has been used in several countries and with different purposes, namely in research and quality enhancement programs (Harms et al., 2003). Results obtained in the present study may contribute to substantiate the use of such a quality measure in the assessment of Portuguese toddler child care classrooms. Despite the low mean results on ITERS-R, we found a normal distribution, with appropriate skewness and kurtosis. Although mean scores at the item level concentrate at the lower end of the likert scale used in ITERS-R and these results could be attributed to problems in item design and/or to strict requirements in the scoring system, a qualitative analysis of the observation records suggests that such findings mirror the actual low-quality of child care provision. Thus, it is important to emphasize that (1) hygiene problems during diapering and toileting as well as during meals and snacks (particularly regarding adult and child hand washing) were frequently observed; (2) in a considerable number of classrooms books were not accessible for children; (3) outdoor space was not frequently used (a considerable number of teachers only provided outdoor activities in the spring); and (4) centers did not promote in-service training for staff members.

In conclusion, the present study expands the evidence base on toddler child care quality, providing information on the applicability of ITERS-R to a new culture and language environment, and simultaneously suggesting the need to make a deliberate investment in quality assessment and enhancement. It is outside of the scope of this paper and beyond the inferences warranted by our data to provide definite explanations as to why Portuguese child care classrooms serving toddlers present lower mean scores on the ITERS/ITERS-R than the Netherlands, Germany, UK, Greece, and the USA. Such differences in the quality of child care and education services are, most likely, multidetermined and Portuguese early childhood education researchers are well advised to analyze the foundations for the present level of quality in toddler child care classrooms. Tentatively, we argue that these differences may be partially related to (1) the historically, legally, and politically determined "caretaking" nature of the services provided to groups of infants and toddlers, estranged from an educational perspective; (2) the impoverishing legacy of a society that 35 years ago had high illiteracy rates and that, although increasingly educated, 
still has education rates below average in OECD (OECD, 2006); (3) the low (although increasing) critical mass of scientific production in the field of early childhood development and education; (4) the nonexistence of a coordinated vision for early childhood that brings together education, welfare, health, employment, and family policies (Alarcão, 2008); and (5) the insufficient resources of a society that struggles with poverty rates above the mean of OECD countries (Instituto Nacional de Estatística, 2006).

As suggested by our findings, teacher training and education seem to constitute necessary pathways to improve toddler child care quality. A considerable proportion of lead teachers in toddler classrooms do not have a college degree in Early Childhood Education and the lead teachers that do have a college degree in early child care and education received training that was clearly focused on preschool-aged children (that is, on working with children between 3 and 5), neglecting child care practices focusing on infants and toddlers.

The improvement of the quality of care provided to younger children may be helped if parents can identify good-quality child care centers (Cost et al., 1995). Available data suggest that Portuguese families that chose infant-toddler child care as an education and care resource are limited in their selection capacity for a number of reasons: (1) the limited number of programs available (Instituto da Segurança Social, 2005c), (2) the relative homogeneous quality of existing classrooms (Aguiar et al., 2002), (3) the lack of relevant information on quality criteria for infant-toddler child care, and (4) the impossibility to access results of quality assessments by independent observers (Cryer, Tietze, \& Wessels, 2002). Considering this picture, necessary direct intervention strategies aiming at improving child care settings' structural and process characteristics must be complemented with systematic efforts aiming at helping parents become more discriminating in their choices, and therefore, increasing their power to affect child care settings quality (Cryer et al., 2002). Furthermore, centers should be actively engaged in the effort to enhance the quality of programs serving toddlers and, as stated by Mathers et al. (2007), ITERS-R should be used "with" centers to encourage the self-evaluation process and not simply applied "to them" as a monitoring tool.

\section{Acknowledgements}

Authors were funded by Fellowships from the Fundação para a Ciência e a Tecnologia (References BD/10721/2002 and $\mathrm{BPD} / 26383 / 2006$, respectively). The authors thank the teachers and directors of the centers that participated in this study as well as research team members Carla Peixoto and Mónica Silva.

\section{References}

Abreu-Lima, I., \& Nunes, C. (2006). A Escala de Avaliação do Ambiente em Educação de Infância-Versão Revista [The Early Childhood Environment Rating Scale-Revised Edition]. In: C. Machado, L. Almeida, M.A. Guisande, M. Gonçalves, V. Ramalho (Coord.), Avaliação Psicológica: Formas e Contextos. Vol. XI. (pp. 634-643). Braga: Psiquilíbrios Edições.

Aguiar, C., Bairrão, J., \& Barros, S. (2002). Contributos para o estudo da qualidade em contexto de creche na Área Metropolitana do Porto [Contributions for the study of toddler child care quality in the metropolitan area of Porto]. Infância e Educação: Investigação e Práticas, 5, 7-28.

Alarcão, I. (2008). Considerações finais e recomendações do estudo [Final considerations and study recommendations]. In Conselho Nacional de Educação (Ed.), A educação das crianças dos 0-12 anos (pp. 114-127). Conselho Nacional de Educação. Retrieved from http://www.cnedu.pt/files/ESTUDO.pdf.

Bairrão, J. (1998). O que é a qualidade em educação pré-escolar? [What is quality in preschool education?]. In Ministério da Educação (Ed.), Qualidade e projecto na educação pré-escolar (pp. 43-88). Ministério da Educação.

Barros, S. (2007). Qualidade em contexto de creche: Ideias e práticas [Quality in infant-toddler child care: Ideas and practices]. Unpublished doctoral dissertation, University of Porto.

Bisceglia, R., Perlman, M., Schaack, D., \& Jenkins, J. (2009). Examining the psychometric properties of the Infant-Toddler Environment Rating Scale-Revised Edition in a high-stakes context. Early Childhood Research Quarterly, 24, 121-132.

Bryant, D. M., Burchinal, M., Lau, L. B., \& Sparling, J. J. (1994). Family and classroom correlates of Head Start children's developmental outcomes. Early Childhood Research Quarterly, 9, 289-309.

Cost, Quality, \& Child Outcomes Study Team. (1995). Cost, quality, and child outcomes in child care centers: Public report (2nd edition). Denver: Economics Department, University of Colorado at Denver.

Creches e jardins-de-infância [Infant-toddler and preschool child care]. (2001, July/August). Proteste, 216, 6-11.

Cryer, D., \& Burchinal, M. (1997). Parents as child care consumers. Early Childhood Research Quarterly, 12, 35-38.

Cryer, D., Tietze, W., Burchinal, M., Leal, T., \& Palacios, J. (1999). Predicting process quality from structural quality in preschool programs: A cross-country comparison. Early Childhood Research Quarterly, 14(3), 339-361.

Cryer, D., Tietze, W., \& Wessels, H. (2002). Parents' perceptions of their children's child care: A cross-national comparison. Early Childhood Research Quarterly, $17,259-277$.

European Child Care and Education Study Group. (1997). European Child Care and Education study: Cross national analyses of the quality and effects of early childhood programmes on children's development. Final report for work package \#1 submitted to European Union DG XII: Science, Research and Development RTD Action: Targeted Socio-Economic Research. Unpublished Report.

Gevers Deynoot-Schaub, M. J. J. M., \& Riksen-Walraven, J. M. A. (2005). Child care under pressure: The quality of Dutch centers in 1995 and in 2001. The Journal of Genetic Psychology, 166, 280-296.

Goelman, H., Doherty, G., Lero, D. S., LaGrange, A., \& Tougas, J. (2000). You bet I care. Care and learning environments: Quality in child care centres across Canada. Retrieved 25 June 2004, from http://uoguelph.ca/cfww.

Harms, T., \& Clifford, R. M. (1980). The Early Childhood Environment Rating Scale. New York: Teachers College Press.

Harms, T., \& Clifford, R. M. (1993). Studying educational settings. In Spodek (Ed.), Handbook of research on the education of young children (pp. 477-491). New York: Macmillan Publishing Company.

Harms, T., Clifford, R. M., \& Cryer, D. (1998). The Early Childhood Environment Rating Scale (Revised Edition). New York: Teachers College Press.

Harms, T., \& Cryer, D. (2003). Video observations for the Infant/Toddler Environment Rating Scale (Revised Edition). New York: Teachers College Press.

Harms, T., Cryer, D., \& Clifford, R. M. (1990). Infant/Toddler Environment Rating Scale (ITERS). Frank Porter Graham Child Development Center. University of North Carolina at Chapel Hill.

Harms, T., Cryer, D., \& Clifford, R. M. (1999). Infant/Toddler Environment Rating Scale. Retrieved July 2002, from www.fpg.unc.edu/ ecers/iters.html.

Harms, T., Cryer, D., \& Clifford, R. M. (2003). Infant/Toddler Environment Rating Scale - Revised Edition (ITERS-R). New York: Teachers College Press. 
Harms, T., Cryer, D., \& Clifford, R. M. (2004). Infant/Toddler Environment Rating Scale-Revised Edition (ITERS-R) (S. Barros, Trans.). Unpublished translation (Original work published 2003).

Hestenes, L. L., Cassidy, D. J., Hegde, A. V., \& Lower, J. K. (2007). Quality in inclusive and noninclusive infant and toddler classrooms. Journal of Research in Childhood Education, 22(1), 69-84.

Instituto da Segurança Social. (2005a). Manual de processos-chave: Creche [Key-processes manual: Infant-toddler child care]. Ministério da Segurança Social e do Trabalho.

Instituto da Segurança Social. (2005b). Modelo de avaliação da qualidade: Creche [Infant-toddler child care quality assessment model]. Ministério da Segurança Social e do Trabalho.

Instituto da Segurança Social. (2005c). Relatório de actualização 2005-2006 do Plano Nacional para a Inclusão [2005-2006 update report of the National Inclusion Plan]. Retrieved 27 June, 2006, from http://www.dgeep.mtss.gov.pt/estudos/peis/rapnai0506_pt.pdf.

Instituto Nacional de Estatística. (2005). Grande Área Metropolitana do Porto [Great Metropolitan Area of Porto]. Retrieved December 2006, from http://www.ine.pt/prodserv/Edi_Bolso/pdf/2005/Norte/GaMP_web.pdf.

Instituto Nacional de Estatística. (2006, December). Indicadores sociais, Edição de 2005. Destaque. Informação à Comunicação Social [Social indicators, 2005 Edition. Highlights. Information to the media]. Retrieved 31 January, 2007, from http://www.ine.pt/portal/page/portal/ PORTAL_INE/Destaques?DESTAQUESdest_boui $=74639 \& D E S T A Q U E S m o d o=2$.

Mathers, S., Linskey, F., Seddon, J., \& Sylva, K. (2007). Using quality rating scales for professional development: Experiences from the UK. International Journal of Early Years Education, 15(3), 261-274.

Mathers, S., \& Sylva, K. (2007). National evaluation of the Neighbourhood Nurseries Initiative: The relationship between quality and children's behavioural development. SureStart Research Report SSU/2007/FR/022. Retrieved 21 May, 2009 from http://www.dcsf.gov.uk/ research/data/uploadfiles/SSU2007FR022\%20REV.pdf.

National Association for the Education of Young Children. (1997). Developmentally appropriate practice in early childhood programs serving children from birth trough age 8 . Washington: NAEYC.

National Association for the Education of Young Children. (1998). Accreditation criteria and procedures: Summary of a position statement of the National Association for the Education of Young Children. Washington: NAEYC.

National Institute on Child Health and Human Development. (2000). The NICHD Study of Early Child Care. Retrieved 14 June, 2002 from http://www.childresearch.net/CYBRARY/EDATA/NICHD/DATA03.HTM.

National Institute on Child Health and Human Development Early Child Care Research Network. (2005). Child care and child development: Results from the NICHD Study of Early Child Care and Youth Development. New York: The Guilford Press.

Organization for Economic Co-operation and Development. (2000). OECD country note: Early childhood education and care policy in Portugal. Paris: Organization for Economic Co-operation and Development. Retrieved from. http://www.oecd.org/dataoecd/52/30/2534928.pdf

Organization for Economic Co-operation and Development. (2001). Starting strong: Early childhood education and care. Paris: Organization for Economic Co-operation and Development.

Organization for Economic Co-operation and Development (2006). Economic survey of Portugal, 2006. Policy Brief. Retrieved 5 May, 2006 from http://www.oecd.org/document/63/0,2340,en_2649_34569_36482175_1_1_1_1,00.html.

Peisner-Feinberg, E. S., \& Burchinal, M. R. (1997). Relations between preschool children's child-care experiences and concurrent development: The Cost, Quality, and Outcomes Study. Merrill-Palmer Quarterly, 43, 451-477.

Peisner-Feinberg, E. S., Burchinal, M. R., Clifford, R. M., Culkin, M. L., Howes, C., Kagan, S. L., et al. (2000). The children of the Cost, Quality, and Outcomes Study go to school: Technical Report. Chapel Hill: University of North Carolina at Chapel Hill, Frank Porter Graham Child Development Center.

Pessanha, M. (2005). Vulnerabilidade e resiliência no desenvolvimento dos indivíduos: Influência da qualidade dos contextos de socialização no desenvolvimento das crianças [Vulnerability and resilience in the development of individuals: Influence of socialization contexts in children's development]. Unpublished doctoral dissertation, University of Porto.

Petrogiannis, K. (2002). Greek day care centres' quality, caregivers' behaviour and children's development. International Journal of Early Years Education, 10 , 137-148.

Phillips, D., Mekos, D., Scarr, S., McCartney, K., \& Abbott-Shim, M. (2000). Within and beyond the classroom door: Assessing quality in child care centers. Early Childhood Research Quarterly, 15(4), 475-496.

Tietze, W., \& Cryer, D. (2004). Comparisons of observed process quality in German and American infant-toddler programs. International Journal of Early Years Education, 12, 43-62.

Tietze, W., Cryer, D., Bairrão, J., Palacios, J., \& Wetzel, G. (1996). Comparisons of observed process quality in early child care and education programs in five countries. Early Childhood Research Quarterly, 11, 447-475.

van Ijzendoorn, M. H., Taveccio, L. W. C., Stams, G. J. J. M., Verhoeven, M. J. E., \& Reiling, E. J. (1998). Quality of center day care and attunement between parents and caregivers: Center day care in cross-national perspective. The Journal of Genetic Psychology, 159(4), 437-454.

Vandell, D. L., \& Wolfe, B. (2000). Child care quality: Does it matter and does it need to be improved? Washington: Institute for Research on Poverty. University of Wisconsin-Madison. Retrieved 20 June, 2002 from. http://aspe.os.dhhs.gov/hsp/ccquality00/ccqual.htm

Vasconcelos, T., Orey, I., Homem, L. F., \& Cabral, M. (2002). Educação de infância em Portugal: Situação e contextos numa perspectiva de promoção de equidade e combate à exclusão [Early childhood education in Portugal: Situation and contexts in a perspective of promotion of equity and eradication of exclusion]. Conselho Nacional de Educação.

Vermeer, H. J., van IJzendoorn, M. H., de Kruif, R. E. L., Fukkink, R. G., Tavecchio, L. W. C., Riksen-Walraven, J. M., et al. (2008). Child care in the Netherlands: Trends in quality over the years 1995-2005. The Journal of Genetic Psychology, 169, 360-385. 